\title{
MAG, WAT KAN? \\ OVER GENETISCHE MANIPULATIE*
}

\author{
E. SCHUURMAN, Vrije Iniversileit, Amsterdam.
}

\begin{abstract}
ABSTRTAC:'T
In the course of the development of lechnology the ethical question as to solhether indeed man "may" do all that he is "able" to do frequenlly rears its head. In this article ethical issues are rassed with regard to the problems surrmunding genstic mamipulation. I'arinus experiments in the field of genetics, the possibilities of application of these and the orthical responsubility of the scientists innolved are discussed. Allention is dirested especially at the genetic manipmlation of man as in. for example, test-tube haby terlmiques. A stand is taken against experiments with aborted foetuses, test-lube babies and sloning. Manipulation of the total genetic composition of man is rejected uncquirocally.
\end{abstract}

In de ontwikkeling van de techniek is altijd al de vraag aanwezig geweest of alles wat gemaakt kan worden ook gemaakt mag worden. Vorral in de moderne - op de nat uurwetcnschap gefundecrde - technick keert die vraag al en toe in alle hevigheid terug. Dat was bijvoorloceld het geval toen de sloomt rein zijn intrede deed. Er waren er die daartegen hevig prolestecerden, umclat ze dachien dat dool het vele lawaai van de trein de kippon straks geen eicren en de koejen gecn molk meer zouden geven.

Mecr dan ecns wordt dit voor heclel gebruikt om te laten zien dat we ons in de ethische bezinning kunnen vergissen. Mecstal wordt daaraan de conclusie verbonden dat we ongehinderel nicuwe wetenschappelijke kennis kunnen torpassen. Toch laat de ethische vraag zich nooit volledig onderdrukken. Dat bleck en blijkt uit de discussic rond de toepassing van kernfysica. Zowel de ontwikkeling van kernwapens als het vrcedzaam

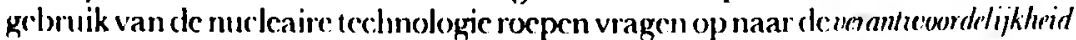
voor de nicuwste wetenschappelijke mogelijkheden en technische prestaties. Maar bijna altijd komt dic vraag als mosterd na de maaltijl. Zo wordt ook nog stcerls de vraag naar lict verantwoord zijn van de ruimtevaart gestelel, Irewijl die onlwikkeling in volle gang is. ()verigens zal niemand willen ontkennen dat de vraag gerechtuaardigel is of het vele getel dat in die onl wikkeling wordt gestoken, wel verantwoord is als we zien dat nog stecds te weinig gedaan wordt aan het honger- en armocelerproblecm in cle wereld.

- (B)rgencerm uil Breerging, 4i(1) Auk. 1982

Koers, 47(4) 1982 


\section{E. Schuurman}

De laatste tijd komt de ethische vraag in verband met nicuwe mogelijkheden weer in het centrum van de aandacht. Dal hangt samen met het sne opschuiven van nieuwe wetenschappelijk-technische fronten, zoals de informatic- of computertechnick on de technologic van de genetische manipulat ie. Maar ook nu wecrzien we dat de gangbare trend ongehinderd wordt voortgezet. Alhoewcl allerwege de verontrusting over deze nieuwe technologische macht van de mens grocit, wordt nog steeds gedaan, wat gedaan kan worden. Zo zegt de gynacculoog prof. Haspels op een symposium aan de universiteit van Utrecht over het. S/eutelen aan menselijke genen, dat het voor ceu chische bezinning op de ter hnick van de reageerbuisbaby te laat is. I)co ontwikkeling is in volle gang en - zegt hij - daarom niet meer tegen te louden.

licn dergelijk berocp op wat gaande is, doct ook Prof. Frielink - hoogleraar in de informatica aan de universitcit van $\Lambda$ msterclam - op cen symposium aan de $V$ U over 'War with the chips?' Hij houdt zich bezig met de vraag of de invorring van de chips, gexien de maatschappelijke gevolgen, wel geoorleofd is. Hij zegt dat voor hem het beslissende criterium dat van de vrije markt is: 'DC' gebruikelijke methode van meting van waarden is via het geld dat iemand voor iets over heeft, anders gezegd via de markt. $\Lambda$ ls iemand een betere methode weet, laat he'n dat snel vertellen; maar dan moet 'beter' nict belekenen, meer 'ethisch verant woord', doch wel efferticver en efficienter'.

Met een dergelijke argumentatie: van liriclink wordt de automat iscring van het groot winkelledrijf verdedigd. De invocring van de zogenaamde strecpjescode mag dan veel werklooshicid verooryaken, deze nieuwe technick is wel docltrelfend en doclmatig. Voorzover de groci in de materiële welvaart al onder druk is komen te' staan, zal deze nicuwe computertechick vanwege mogelijke prijsverlagingen daaraan weer ecn positieve bijdrage leveren. Iat de vele dimensies van het 'winkelen', waaronder de sociale niet de minst belangrijke is, daarmec gereducecrd worden tot een slechts technische artiviecit, is de prijs die daarvoor betaald moct worden.

Overigens maakt dit voorbectd wei duidedijk dat er normen geacecpecerd worden. De ontwikkcling komt niet zonder ons over ons. Sinds de secularisatie van de christelijke heilsverwachling in een materialist ische vooruit gang in de fundering van de nommativiteil echter ecen binnenwereldlijke grworden. Dáárdonr komt hel dat men zegt geen behoefte meer te hebben aan e'n 'meer ethisch verantwoorde' oplossing. 


\section{Genetische manipulatie}

Toch zullen we in deze gang van zaken niet mogen berusten. De mens is immers verantwoordelijk; ten diepste verantwoordelijk tegenover God. Daarom kan hij niet om de vragen heen: waartoe dienen nieuwe wetenschappelijke tocpassingen, welke gevolgen veroorzaken ze, bevorderen ze de rechtvaardighcid in de samenleving, welke normen moeten we bij de beoordeling accepteren, enz? En naast bezinning op ontwikkelingen die zowel positicve als negatieve gevolgen hebben, moet ook de vraag aan de orde komen of er mogelijk ook nicuwe technieken zijn die als zodanig fout en dus al te wijzen ziin.

Deze vragen wil ik in dit artikel aan de orde stellen rond de problematiek van de genetische manipulatie. Daartoe behoort vooral de mehode van het recombineren van genetische informatie - de zogenaamde RecombinantJ)NA - maar niet minder de technick van de reageerbuisbaby, de kunsımat ige inseminatie, enz. Vooral de laatste mogelijkheden krijgen door de nicuwe $\mathrm{R}$-I)N $\Lambda$-techniek een nieuwe stimulans.

\section{HET EXPERIMEN'T}

Momenteel verkecrt de genet ische manipulatie, in de zin van het uitwisselen van genetische informatic tussen de verchillende soorten, voor het grootste decl nog in de fase van het onderzoek. Veel wetenschappelijke onderzockers zijn van mening in het wetenschappclijk onderzoek niet met ethische problemen te maken te heblen. Die zouden zich cerst gaan voordoen wanneer deze nieuwe biotechnologie industriëel wordt toegepast of invlocd krijgt op de landbouw, veeteelt en geneeskundc. Fundamentcel wetenschappelijk onderzoek wordt beoefen om kennis te verwerven, zo wordt gezcgd. In het toegepast wetenschappelijk onderzoek en vooral bij de industriële toepassingen zouden pas ethische vragen actueel worden.

Dat dit een verkeerde benadering is blijkt uit de experimenten in het funclamentecl wetenschappelijk onderzoek. Aan dat experienteren zitten nogal wat vragen vast. Aan dat experimenteren zitten nogal wat vragen vast. Bovendien mag niet worden vergeten dat fundamentecl wetenschappelijk onderzock een stap is op weg naar - al of niet grootschalige - toepassing. In die fase moeten reeds de cthische vragen aan de orde worden gesteld, al was het allecn om niet straks opnieuw het veelgehoorde verwijt uit te lokken dat ethische vragen niet meer relevant zijn, omdat de ontwikkeling al in volle gang is. 


\section{E. Schuurman}

\section{Ontwikkrling van de geslachtacellen}

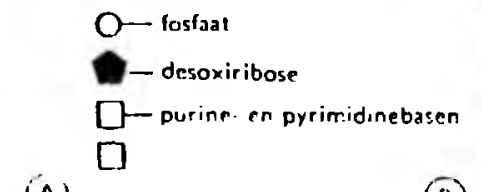

(4)

(e)
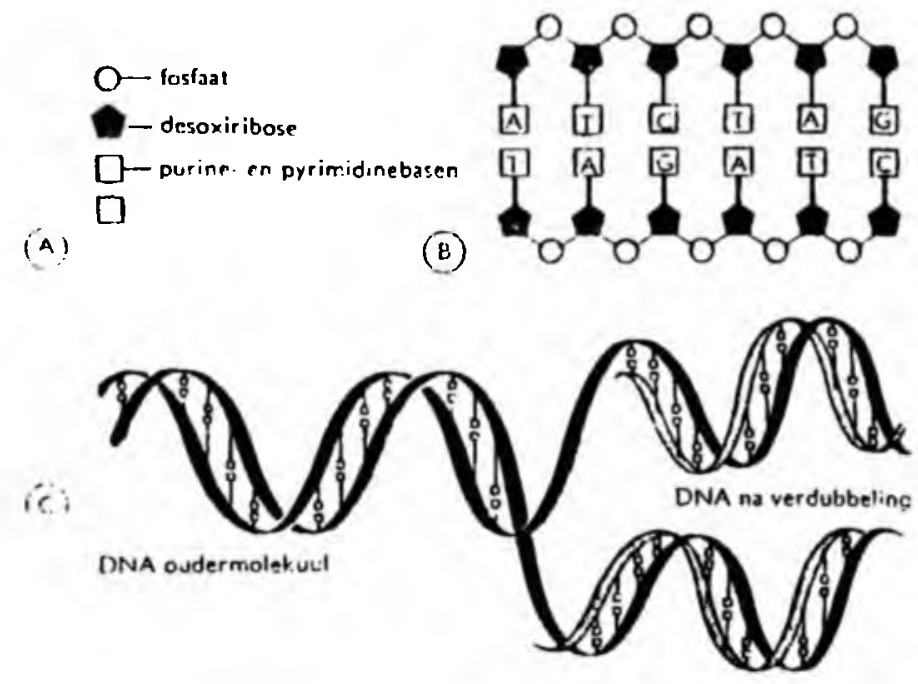

(1) [

(1)

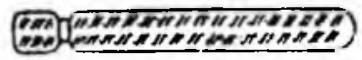

(E)

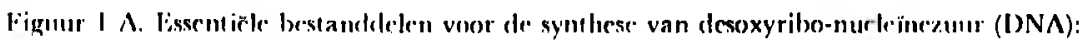
foslaal, resoxyribose en purine. (adconine en guanine) en pyrimidincbasen (thymime en cytosine). B. Silhematise he voorstelling van leet DNA-molekuml. 'Twere polynucleotiden dijn op' zodanige wijze met elkaar verbonden donr zijketens van de basen dal adenine (A) cen par vorme me- thynine ("I"), en guanine ((;) met cytosine (C). (: I)iagram van de verdubbeling van het I)NA-mole-kıml. I,inks her ouelernolekuml met de complementaire spiralen verbonden demr zijketens van de basen; de rechteskant toont de veretubbeling van de spiralen. Naclat de watcostelbnuggen lussende lasen zijn verloroken, wudener twer nieuwe DNA-strengen gesynthet isered. De nienwe spiralen vertomen cen basensamenstelling die complementair is ano die van de

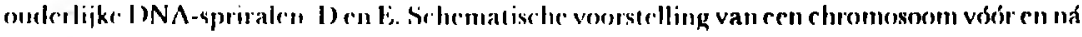
de I) NA-verdubbcling.

(C)er genomen uit J. I,angman. Inleicling Iof de cmbryologic, Amsterdam, 1969.)

Maar laten we eerst aandaclıt geven aan het experiment. Sinds Galilei vormt het cen machtig 


\section{Genetische manipulatie}

midrlel om tot welenschappelijke kennis te komen. Via het experiment krijgen we ant woord op een wetenschappelijke vraag. Daartoe richten we experimentecl ecn stukje werkelijkheid kunstmalyg in. We gaan in lect experiment van de gegeren werkelijkheid uit, maar brengen daarin zodanige veranderingen aan, dat we ćrnduidige antwoorden krijgen op onze abstracte, wetenschappelijke vragen.

Reeds op de iniddelbare school hebben we allemaal in de natuurkunde met experimenten kennis kunnen maken. Daartegen zijn weinig bezwaren in te brengen. Heel anders wordt dat al wanneer we experimenten gaan doen met dicren. Velen achten vivisectie - het doen van procven met dieren voor wetenschappelijke doclen - ethisch onverantwoord. Dat gevoclen is zelfs z.o algemeen geworden dat er hij wet maatregelen genomen zijn om het doen van procven met dieren te beperken en, indien het onontkombaar is, het aan bepaalde voorwaarden te onderwerpen. Merkwaardig genocg kennen we dergelijke maatregelen nog niet als het gaat om het doe'n van prorven met nensen. Wel zijn binnenkort wettelijke maatregelen te verwachten waarbij ook deze experimenten aan begrenzende voorwaarden worden onderworpen. Dat beteken dat er blijkbaar ook met mensen in toenemende mate wordt gecxperimenteerd. In elk geval maakt deze situatie duidelijk dat we in biologie en geneeskunde eerder met ethische problemen te maken heblen dan in de /vsica. Dringende aandacht voor deze ethische problematick is vereist, wanneer men er vanzelfsprekend van uitgaat dat experimenten geoorloofil zijn omdat daarmec het hoge idcaal van nicuwe wetenschappelijke kennis wordt bevorderd. Aanvankelijk kan dat misschien ook wel zonder bezwaar gebeuren. Voortgaand wetcnschappelijk onderzock cist echter meer verlijincle en geraflineerde experimenten oin antwonden te kunnen vinden op steeds dieper reikende wetenschappelijke vragen. Zelfs de fysica ont kom daaraan nict langer. Wanneer procven met bijvoorbereld raclioacticf materiaal worden geclaan, zijn cthische vragen nict meer uit te sluiten. Maar wanneer in dir biologie levende wezens voor procven worden gebruikt, zijn van meetal aan ethische vragen present. Dit doet zich momented voor in de moleculaire biologie. Om meer inzicht in het functioneren van levende wezens te krijgen wordt op grote schaal onderzock gedaan nar de structuur van de DNA-molecule dic als fundamentele bouwsteren dient veor de informatie van alle levende wezens, zij het dat deze molecuul van soort verschilt wat betreft de structuur en functir.

In de moleculaire biologie is de laatste tijol cen lepaalde experimentermelhode ont wikkeld om meer te weten te komen van die opbouw en het functioneren van de I) N $\Lambda$-molecule. Men brengt stukjes van de $\mathrm{D} N \Lambda$-molecule van e'en 


\section{E. Schuurman}

bepaalde soort binnen de DNA-molecule van ecn bacteric. Deze bacterie wordi dus met een vreend stukje I NA 'verrijkt' of 'kreupel' gemaakt.

Natuurlijk doet inen dergelijke procven niet met pathogene, zickteverwekkende barteriën, maar met bacterién die onschadelijk zijn voor mens, dier en milieu. Men geloruikt hicr bacteriën omdat deze zich sncl ontwikkelen en daardoor ved van dat geisoleerde stukje I)N $\Lambda$ produceren tegclijk met de stof waarvoor dat stukje DN $\Lambda$ 'verant woordclijk' is.

In 1974 - dus nog geen tien jaar geleden - hesloten de geleerden in Amerika met deze proeven te stoppen, omdat door dezc experimentecrmethode mogelijk 'verrijktc' of 'kreupele' bacteriën zouden kunnen ontstaan, die hoewel de gastheer zell niet pathogeen is, zickteverwekkende bacterien zourlen kunnen worden, waartegen mogelijk geen kruid gewassen is

Dit verbod heeft nict lang geduurd. I it procven onder zeer strenge vciligheidsmaatregelen bleck lle aanvankelijke ongerustheid ongegrond. Wel moesten de procven nog a an e'n aantal nauwkeurig omschreven eisen en veiligheidsvoorschriften volfloen. Omclat uit de toegenomen ervaring met procven blijkt dat de aanvankclijke vrecs ongerceht vaardigd is, worden de regels voor de experimenten voortdurend versoepeld. Waakzaamheid blijlt echter geboden, omdat niet van alle mogelijke experimenten met bacteriën is komen vast te staan dat ze ongevaarlijk zijn.

Het ligt voor de hand dat deze nicuw verkregen kennis van de genet ische informatie gebruikt wordt. Met deze kennis ligt de mogelijkheid open om die informatie opnieuw te rangschikken, te wijzigen en dus te manipuleren. Aan dezc manipulatie, waarbij onderdelen van de genet ische informatic van cen hogere soort in cen lagere soort, bacterien of schimmels worden ingeluracht, zijn mijns inziens op zichself, bij voldocnde bevciliging, geen doorslaggevende ethische bezwaren in te brengen. Sommigen denken dat dit vanwege de soortvermenging wel het geval is; ten onrechte, aangezien slechts cen s/uhje I N $A$ van de enc, hogerce soort binnen hel onl wikkclingsproces van een andere, lagere soort wordt onderzoclit.

\section{TOEPASSINGEN}

Wrl leidt de Recombinant-DNA-technologic tot grootschalige toepassingen, waaraan we vecl te danken kunnen hebben, maar waaraan opnieuw chische kwesties verbonden zijn. Uil een rapport van een commissic die zich speciaal met deze biotechnologie heeft bezig gehouden, blijkt hoezecr 


\section{Genetische manipulatie}

het recombineren van IDNA nieuwe ontwikkelingen tot gevolg herfi in de larmacie. de landl)ouw, de vecterle de genceskunde en in allerlei industriële: processen.

Momentecl wordt al insuline geloruikt voor de behandeling van suikcrzickte, via deae biotechnologie geproduceerd. ()ok is het mogelijk gebleken allerlei soorten interferon te produceren, waarvan gezegel worde dat dit cen gencesmiddel tegen kanker kan zijn. Ook is al cen bacterie gecombineerd die cen veiliger entstol tegen mond-en klauwzecr kan produceren. Men hoelt dic entstof niet mece te isoleren uit" gevaarlijke vitussen. Jeze stof wordt geproduceerd door een bacteric waarin het stukje I) NA is ingebrache dat voor rle productic crvan 'verantwoordelijk' is.

Met de nieuwe technologie kunnen de problemen en gevaren van een syuthelische chemic voor cen decl worden overwonnen wanneer men gebruik gaat maken van gerecombincerde organisınen. ()ok denkt men met de recomblinant-DNA-technologie bacterièn te kunnen maken die olie eten of zware metalen afbreken. I aarmec zou de milieuvervuiling waarvool de mens veranewondelijk is, door gerecombincerde bacterien te nict kunnen worden gedlaan. (Ook werkt men aan de'constructie' van planten dic rechtstrecks stikstof uit de lucht mocten kunnen hinden. Dat zou veel en clunr kunstmest overbodig maken en tegelijk een oplossing kunne'n bieden voor het groriende hongerprobleem in de wereld.

Voor het merended is dit alles nog torkomstmuzick. Er inoel nog veel onderzoek woiden gedaan, vooral naar de mogelijk negaticve gevolgen van inclustriele toepassingen. Fen bij uitstek ethise he kwest ie is, of het veranl woord is om op grote schaal nicuw gecrëerde hacteriën in het milieu te brengen. Werdt daarmec het bestaande evenwichl nict verstoord, en zo ja, net we:lke gevolgen!' I "I sommige kringen is de zorg laarover zo groot, dat men zich - evenals tegen kernreactoren - ook gaat verzetten tegen tockomstige bioreactoren en tegen de groots heepse introductic van gercombinererle hacterien in het milieu.

Ik denk dat inderdaad grote voorzichtigheid geboden is. Hel Iorstaande recombinant - DN $\Lambda$-onderzork mag dan verant woord $z$ iju indien het voldoet aan (laarvoor geldende eisen, onmiskenbaar zal grootschalige tocpassing er van gevaren in zich bergen. In elk geval zal dat gelden vone de productie van nieuwe bilogise he wapens waartoe de nieuwe wetens bappelijke kemmis een aanze kan vormen. Maar ook in het geval van vrecdzame lecepassingen mag niet werrlen vergeten, dat we daarmee nog geen enkele ervaring helhen en 


\section{E. Schuurman}

het complex van gevolgen oumogelijk van tevoren kunnen kemnen. De les van de huiclige industriële techniek is dat er altijd negatieve gevolgen zijn die we nict hij voorbaat hebben kumnen overzien. Die les moeten we dan ook ter harte nemen. Het getuigt van een te groot optimisme wannecr we cr vanzelfsprekend van uitgaan, dat met deze nicuwe technick de kwalen van andere technicken kumnen worden genezen.

\section{VERANTWOOR DELIJKHEID VAN DE WETENSCHAPPER}

Vanwege de problemen cn gevaren die in toenemende mate verbonden zijn aan het experimenteren en aan de industricle tocpassingen, en met het oog op verkecrl gebruik van op zichzelf gocele wetenschappelijke kennis, wordt er terechl vecl aandacht gevraagd voor de verantworodelijklieid van de wetenschapper. Dat was ook al wel cerder aan de orde. Bekende voorbeclden zijn: Is Otto Hahn als kernfysicus verantwoordelijk voor Hiroshima? Zijn kcrnlysici verant woordelijk voor de ont wikkeling van kernwapensystemen die, omclat ze in technisch opzicht steeds minder te beheersen zijn, tot cen demonische catast rofe kunnen leiden? Het ligt voor de hand dat dergetijke vragen opnicuw gesteld worden nu het in het wetenschappelijk onderzock tot nicuwe doorbraken is gekomen. Het recombineren van genetisch materiaal kan naast positieve ook negalieve gevolgen hebben, zo zagen we al. Is de onderzocker claarvoor verantwordelijk? Ja, zegt men, als het om het onderzock als zodanig gaat. Maar horvecl ic zwaarder zon dic verant woordelijkheid mocten wegen t.a.v. mogelijk onomkeerl)are gevolgen van de IDNA-technologie voor mens, dier en milicu.

Terecht brengen anderen tegen ecen dergelijke redenering het bezwaar in dat niet worde nagegaan of de: nadelige gevolgen nict nog groter kunnen zijn, wannecr men van bepaalde biolechnologicen zou afzicn. Als voorbeck ligt het hongerprobleem vour de hand.

(iegrven deze dubbelzinnige situatic kunnen de ane woorden op de vragen naar de verantwoordelijkheid van de wetensehapper niet altijd cenvoudig zijin. Wel groxit het besef dat wetenschappers met cle introductic van nicuwe teroologicion erg voorzichtig mocten zijn. De: wetenschappers en hun organisaties staan cr meer en meer voor open grotere verantwoordclijkhcid te arcepteren. Maar de vorm waarbinnen deze gerealisectd kan worden, vormt momenteel in die kringen en ook in die van politici, cen zaak van ernst ig leraad. Binnen het kader van dit art ikel wil ik daaraan voorbij gaan. Te zijner tijd hoop ik daarop in cen themanummer van BEWE, IINC; over U'slenschup on Siamenleming terug te komen. 


\section{GENETISCHE MANIPULATIE VAN DE MENS}

In het hier volgende wil ik mij beperken tot de cthische vragen rond de mogelijklieden van de genetische manipulatic van de mens. De mens heeft direct of indlirect via de recombinant-DNA-technologie cen marlıt gekregen om ook met de genetische informatic van de mens zèlf te manipuleren. Zijn er aan die macht grenzen, die hij nict mag overschrijden?

De Zwitserse hoogleraar in de moleculaire biologie, Charles Weissmann, hceft gezegd dat binnen niet al te lange tijd de mens, èlke mens, inzicht kan krijgen in de aard, structuur en functie van zijn eigen genen-bestand. Fen gen is de kleinste cenheid van erfelijke informatie. Met de beschreven recombinant-DNA is het mogelijk de erfelijke informatic van de mens in kaart te brengen. Die informatic bestaat uit ongeveer 100000 genen, waarvan er momentecl reeds 10000 zijn onderzocht. Het zal nict lang meer duren of men hecft inzicht in en overzicht van het totale genenbestand van de mens. Met behulp van de computer kan dezc 'gen-mapping' gemakkelijk worden gehanterd.

Wannecr dergelijke genen-prolielen niet worden beschermd, kan daarvan mishruik worden gemaakı, bijv. in de vorm van discriminatie in de werksfeer en het stellen van onvoordelige voorwaarden bij het afsluiten van verzekeringen wanneer uit het genen-bestand erfelijke afwijkingen of grotere risico's op een vroegtijdige dood zouden blijken. Vanzelfsprekend worden de et hische vragen nog dringender wanneer op grond van bekende. genen-profielen van beide ouders uit pre-nataal onderzoek zou blijken dat een kind met een ongunstig genen-bestand geboren wordt. Het gevaar is groml dat dergelijk onderzock het aantal zwangerschapsonderbrekingen zal docn toenemen. Weissmann gaat nog een stap verder. Hij zegt: 'Dicp in mijn hart weet ik dat het op ecn bepaald moment in de tockomst, en dan spreck ik over tientallen jaren, mogelijk zal zij.jn ingewikkelde genet ische veranderingen bij de mens aan te lorengen. Dan zal het hoofd geboden moeten worden aan de chische problemen daarvan'.

In die situatie mogen we dan nu nog niet verkeren, loch staan we reeds op de drempel van cen tijdperk waarin de mens zijn voortplanting buiten de mocderschoot kan manipuleren. Momenteel kunnen ouders met een homologe insemenatic geholpen worden aan een kind waarvan zij de vader en moeder zijn. In geval van een hetcrologe inseminatic wordi ecn kind geloren waarvan de vader onbekend is. De mogelijkheden van de reagecrbuisbaby-technick zullen zodanig toenemen, dat het geslach van 


\section{E. Schuurman}

het kind tevoren kan worden gekozen, dat bevruchte eicellen kunnen worden ingeplant bij totaal vreesnde moeders. Met de reagecrbuisbabytechnick zal het in de toekomst nict allecn mogelijk zijn vroegt ijdig erfelijke defecten op te sporen, maar zal ook de mogelijkheid zich voordoen een super-baby te 'construeren' met een zo gunstig mogelijk genen-bestand.

Het lig! voor de hand dat hicr grote ethische vragen aan de orde zijn. Sommigen waarschuwen er terecht voor dat in deze technieken cen verkwisting plaats vindt van reeds bevruchte eicellen, die om wclke reden ran ook niet geschikt worden geacht voor inplanting of ecnvoudig overbodig zijn. Sommigen hebben als criterium aangegeven dat we in tegenstelling tot vroeger het individucle menselijk leven nict langer onaantasthaat mogen achten, en in plaats daarvan ons slechts dienen te laten leiden door overwegingen $m$. b.t. de kwaliteit van het individuele leven.

Op zock naar cen hoogwaardige kwaliteit van het leven ontmoeten we in de literatuur inmiddels de gedachte dat van cen individu met cen hoog gckwalilicecrd genenbestand meerdere excmplaren zouden mocten worden 'gemaakt'. Men nocmt dit clonen. Dit is een techniek dic inmiddels met muizen en kikkers is geslaagd, maar bij de mens nog geen tocpassing heefi gevonden. Maat, gesteld dat het kán, mag het dan ook? Ook nog op een ander experiment wil ik wijzen. Voor bepaalde onderzoekingen heeft men geprobecrd cen citje van een hamster te bevruchten met het sperma van een man. Het resultaat daarvan is een hybride - cen levensvorm tussen mens en hamster - dat zicht tot 16 ongedifferentieerde cellen kon ontwikkelen. Deze experimenten, ook dic van de reageerbuisbaby-technieken, zijn vooral mogelijk geworden door de legalisatie van de abortus provocatus. Juist vanwege deze legalisatie is elk experiment met het menselijk genoom - het totaal aan genetische informatie - in zckere zin vogelvrij verklaard. Er zijn geen goede regels meer voor vast te leggen. Om dezellde reden wordt er ook niets gedlaan tegen experimenten met geabortecele foetussen, die met kunst en vliegwerk in het leven worden gehouden om zo goed mogelijke onderzoeksresultaten te krijgen. In cen rapport van amerikaanse wetenschappers las ik dat dergelijke experimenten met geaborteerde foetussen zclfs nodig zijn om nieuwe medicijnen uit te testen, dic de gezondheid van de mens ten goede kunnen komen.

Om cen goed inzicht te krijgen in wat in al deze experimenten gaande is, moct worden ingezien dat binnen deze experimenten de mens gereduceerd wordt tot cen abstract object. Dat gebeurde in het verleden reeds in de denkwereld toen men bewcerde dat de mens cen machine, cen naakte of 


\section{Genetische manipulatie}

geklede aap, of ecn ingewikkeld fysich-chemische substantie was. Voor het eerst worden deze 'denkbeelden' in de genetische manipulatie-technicken op de mens teegepast. Vervolgens moet de mens binnen dit 'denkbeeld' worden verbeterd of eventueel nicuw gemaakt. Mocht dat niet direct lukken dan wordt het gemanipulecrde materiaal als waardeloos ter zijde geworpen.

Morten we niet van overmoed en hoogmocd spreken, om tegelijk vast te stellen dat deze nieuwe wetenschappelijk-tcchnische macht over de mens hem reduceert tot louter matcric, waaraan wij naar onze wensen vorm kunnen geven? Waar is hier nog plaats voor de crkenning dat elk individueel mens geschapen is naar het becld van God en dat daarom Gods liefde en zorg naar elk individu moorldurend uitgaat?

In zoverre de mens deze liefde aanvaardt kan hij ook in moderne medische technicken zijn naaste van dienst zijn. Ik denk dan aan het voorbeeld van de gentherapie waarin leukemic genezen kan worden. Ook zou nog verantwoord te denken zijn aan het herstellen van bepaalde genetische defecten. Maar zodra het totale menselijk genoom in de manipulat ic to object wordt, moct cen neen klinken. Dat gebeurt in experimenten met hybriden (in bovengenoemde zin van vormon tussen mens en dier) en met bevruchte eicellen in reageerbuizen, waarvan bovendien een deel niet gebruikt kan worden en dus vernictigd moct worden.

Het uiteindelijk oordcel hicrover is ten diepste allecn bijbels-religicus te funderen. Ook groeit dan het inzicht, dat de verdediging van deze experimenten uitgaat van de geseculariseerde religie van de westerse mens dic zich in de ontwikkeling van Renaissance, rationalisme cu verlichting meer en meer overgeeft aan de afgoderij met de mensclijke rede en de technische macht.

Ik vat mijn conclusie samen met de woorden van een christen-denker, Hugo Staudinger, die in de Frankfurter Allgemeine van $12 \mathrm{mei} \mathrm{j.l} \mathrm{over} \mathrm{dezelfde}$ materie schreel: 'Ik veroordecl experimenten op mensen in concentratickampen, ik veroordeel ook alle procven aan en met mensen, die niet vrijwillig daartoe hun goedkeuring geven of hebben kunnen geven. Dat laatste geldt voor debicle patienten, maar ook voor experimenten met geabortcerde foetussen. Ik ben van mening dat dit ook geldt voor reagecrbu isbaby-technieken en het inplanteren van embryo's. En ten slotte behoren alle mislukte en succesvolle manipulaties met het menselijk genoom tot de taboes'. Ik zou tot die laatste categoric ook de hybriden rekenen.

Ik stem met deze conclusie van staudiger vóórshands in. Deze conclusie wordt 


\section{E. Schuurman}

aan de lezers voorgelegd in de hoop dat zij mee willen denken over de normatieve grenzen van deze genet ische manipulatictechnicken.

Het gegeven standpunt maakt mijns inziens duidelijk waar de grenzen tussen gorde en slechte ontwikkclingen liggen. Er blijft dan nog veel bezinning nodig om verantwoorde technicken niet te laten ontaarden in kwadc. 